\title{
THE BLOOD GROUPS OF THE SHONA OF SOUTHERN RHODESIA
}

\author{
E. MASON BARKER \\ Pasteur Institute and Public Health Laboratory, Salisbury, Southern Rhodesia \\ ELIZABETH W. IKIN and A. E. MOURANT \\ Blood Group Reference Laboratory (Medical Research Council) \\ Lister Institute, London, S.W. 1 \\ Received 12.vii. 52
}

THIs paper describes the results of tests for the $\mathrm{ABO}, \mathrm{MN}$ and $\mathrm{Rh}$ blood group systems, carried out on specimens collected in Salisbury, Southern Rhodesia, from members of the Shona tribes. The majority of the persons tested belonged to the Northern Shona group. Tests were carried out locally for the $\mathrm{ABO}$ groups of 377 persons, and a further Ior specimens were sent to London where $\mathrm{ABO}, \mathrm{MN}$ and $\mathrm{Rh}$ groups were determined. Gene frequency calculations were done by the methods described by Chalmers, Ikin and Mourant (1949), and Prasad, Ikin and Mourant (1949), and more fully described by Mourant (1953).

The only previous anthropological blood grouping work done in this region is that of Elsdon Dew (1939).

The A and B gene frequencies calculated from the present work, I 5.7 per cent. of $A$ and 13.4 per cent. of $B$, fall just within the range of rather scattered frequencies found for the Northern Shona tribes by Elsdon Dew. Our values for both genes are near the upper end of Elsdon Dew's range and are near to the values found by him for the Korekore tribe of the Northern Shona group. Members of this tribe probably form a considerable proportion of our subjects but not a majority of them. Elsdon Dew's gene percentages for the Northern Shona as a whole are only $14^{\cdot} \cdot 6$ per cent. of A and I I 2 per cent. of B. For our MN frequencies there is no previous work anywhere in East and South-East Africa with which we can make comparisons. The results agree well with numerous recent unpublished observations in various other parts of Africa.

The $\mathrm{Rh}$ frequencies have a typical African aspect. As far as published papers and work now in progress can show, the differences between different parts of Africa in this respect are slight and only in a few cases statistically significant. The $c \mathrm{D} e$ chromosome is everywhere the commonest by a very wide margin, but is most frequent in the centre and east. In the west and south, however, cde shows higher frequencies than in the east and centre. The $\mathrm{E}$ gene also tends to have a higher frequency in the centre. In these respects the Shona appear, as far as the small number tested can show, to agree with the peoples of West and South Africa rather than with those of the centre. 
They also differ, though barely significantly, from those of East Africa (Kenya and Uganda), (Allison, Ikin and Mourant, 1952;

TABLE I

$A B O$ groups of the Shona

\begin{tabular}{|c|c|c|c|c|c|}
\hline Grou & $\begin{array}{l}\text { Number } \\
\text { observed }\end{array}$ & $\begin{array}{c}\text { Frequency } \\
\text { observed }\end{array}$ & $\begin{array}{l}\text { Frequency } \\
\text { expected }\end{array}$ & $\begin{array}{l}\text { Number } \\
\text { expected }\end{array}$ & $\begin{array}{c}\text { Gene } \\
\text { frequencies }\end{array}$ \\
\hline $\begin{array}{l}\mathrm{O} \\
\mathbf{A} \\
\mathbf{B} \\
\mathbf{A B}\end{array}$ & $\begin{array}{r}235 \\
\mathrm{r} 24 \\
\mathrm{r} 05 \\
\mathrm{r} 4\end{array}$ & $\begin{array}{l}0 \cdot 492 \\
0 \cdot 259 \\
0 \cdot 220 \\
0 \cdot 029\end{array}$ & $\begin{array}{l}0.502 \\
0.248 \\
0.208 \\
0.04^{2}\end{array}$ & $\begin{array}{c}240 \cdot 1 \\
I 18 \cdot 4 \\
99 \cdot 3 \\
20 \cdot 1\end{array}$ & $\begin{array}{c}0.709 \\
0.157 \\
0.134 \\
\ldots\end{array}$ \\
\hline Total & 478 & $\mathrm{I} \cdot 000$ & I $\cdot 000$ & $477 \cdot 9$ & $1 \cdot 000$ \\
\hline
\end{tabular}

TABLE 2

$M \mathcal{N}$ blood groups of the Shona

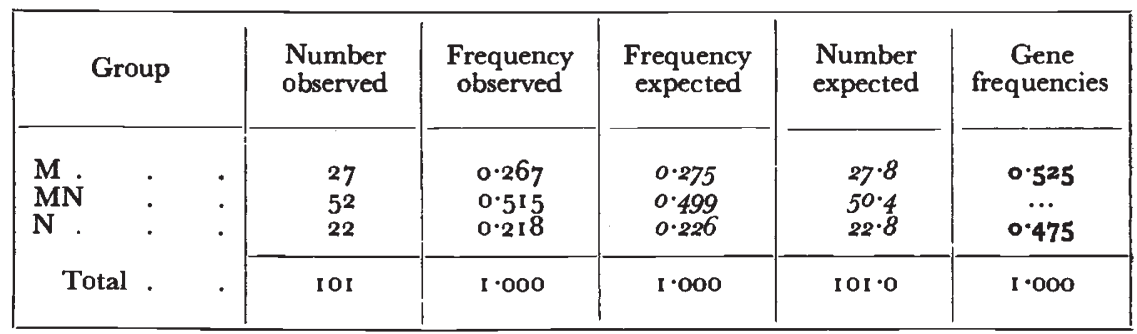

TABLE 3

$R h$ blood groups of the Shona

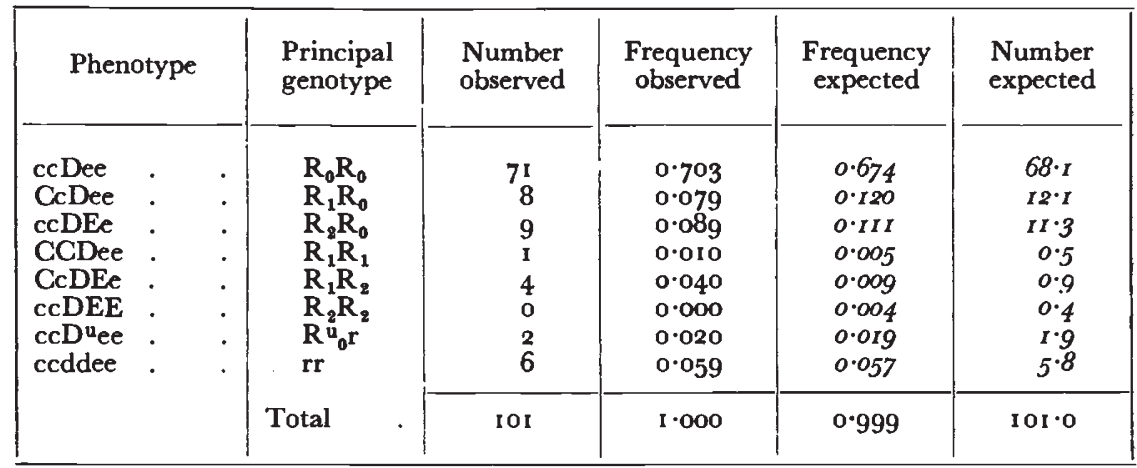

Chromosome frequencies

\begin{tabular}{|c|c|c|c|c|c|c|c|}
\hline \multirow{6}{*}{$\begin{array}{l}\text { cDe } \\
\mathrm{CDe} \\
\mathrm{cDE} \\
\mathrm{cD}^{\mathbf{u}} \mathrm{e} \\
\text { cde }\end{array}$} & \multirow{5}{*}{$\begin{array}{l}R_{0} \\
R_{1} \\
R_{2} \\
R^{u_{0}} \\
r\end{array}$} & • & • & • & - & • & 0.591 \\
\hline & & . & . & . & . & • & 0.069 \\
\hline & & . & • & . & - & - & 0.064 \\
\hline & & . & . & . & . & . & 0.037 \\
\hline & & . & . & . & . & . & 0.239 \\
\hline & & & & & & & $1 \cdot 000$ \\
\hline
\end{tabular}

Ikin, Mourant and Raper, 1952), but the Shona are nearer in their $\mathrm{Rh}$ frequencies to the Bantu-speaking Kikuyu than to the Nilotic 
Luo. It is, however, desirable that the blood groups, and especially the $\mathrm{Rh}$ groups, of the inhabitants of the intervening area should be examined.

There is some evidence that one important basic component of many African populations has an $\mathrm{Rh}$ composition near to that of the Shona, a second with higher frequencies of $\mathrm{cDe}$ and $\mathrm{cDE}$, but lower cde, being typified by the Pygmies of the Belgian Congo (Hubinont and Snoeck, 1949). A detailed account of the variations in frequency of the Rh groups among Africans and of their possible significance is given by Mourant (1953).

\section{REFERENCES}

Allison, A. C., IKIN, ELIZABETh w., AND MOURANT, A. E. I952. Blood groups in some Kenya tribes. 7. Roy. Anthrop. Inst (82, 55-59).

chalmers, J. N. M., ikin, elizabeth w., and mourant, A. E. I949. The ABO, $\mathrm{MN}$ and Rh blood groups of the Basque people. Am. 7. Phys. Anthrop., n.s. 7, 529-544.

ELSDON DEW, R. 1939. Blood groups in Africa. Publ. S. Afr. Inst. med. Res., 9, 29-94.

hUBINONT, P. o., AND SNOEGK, J. 1949. Répartition des gènes Rh (CDE cde) chez les Pygmées Batswa des Ntomba. C.R. Soc. Biol, I43, 579.

IKIN, ELIZABETH W., MOURANT, A. E., AND RAPER, J. A., I 952. Blood groups of the Amba Pygmoids of Uganda. 7. Roy. Anthrop. Inst., 82, 60-6r.

mourant, A. E. 1953. The Distribution of the Human Blood Groups. Oxford (in the press).

PRASAD, C. H., IKIN, Eltzabeth W., AND mourant, A. E. I 949 . The Rh and MNS blood groups of some students from India. Amer. F. Phys. Anthrop., n.s. 7, 553-558. 